\title{
Epigenetik Mekanizmaların Besinlerin Biyoaktif Bileşenleri ile İlişkisi
}

\author{
Relationship between Epigenetic Mechanisms and Bioactive Components of Foods
}

\section{Deniz Mıhçığlu ${ }^{1}$}

Geliş tarihi/Received: 06.11.2019 • Kabul tarihi/Accepted: 31.12.2019

\section{ÖZET}

Deoksiribonükleik asitin (DNA) 1953 yılında keşfedilmesi ve 2003 yılında “İnsan Genom Projesi” nin tamamlanması ile birlikte genetik alanındaki ilerlemeler çok ciddi bir ivme kazanmıştır. Genetik alanındaki araştırmalarda multidisipliner çalışma yaklaşımları da yer bulmaya başlamıştır. Bu yaklaşımlardan birisi de beslenme ve genetiktir. Epigenetik, DNA baz diziliminde herhangi bir değişiklik olmadan, gen ifade profilinin farklılaşarak sonraki kuşaklara aktarılmasıdır. Epigenetik mekanizmalar genlerin ifadesini arttırıp azaltabildiği gibi genlerin sessizleştirilmesinde de etkilidir. DNA metilasyonu, histon modifikasyonları ve kodlanmayan ribonükleik asitler (RNA) başlıca epigenetik mekanizmalardır. Epigenetik modifikasyonlar erken embriyonik dönemdeki gelişim açısından da önemlidir. Son yıllarda yapılan çalışmalar besinlerde bulunan biyoaktif bileşenlerin epigenetik mekanizmalar üzerinde etkili olduğunu göstermiş ve bu alandaki araştırmalar için ilgi çekici olmuştur. Bu derlemede, kromatin yapı, temel epigenetik mekanizmalar açıklanmış ve epigenetik modifikasyonları etkileyen besin biyoaktif bileşenleri ile ilgili yapılmış çalışmalara yer verilmiştir.

Anahtar kelimeler: Epigenetik, Beslenme, DNA metilasyonu, histon modifikasyonu

\begin{abstract}
With the exploration of DNA in 1953 and the end up of the "Human Genome Project" in 2003, advances in genetics have gained considerable progression. Multidisciplinary study approaches have started to take place in genetic researches. One of these approaches is nutrition and genetics. Epigenetics is the transfer of the gene expression profile to the next generation without any alteration in the DNA base sequence. Epigenetic mechanisms can induce or decrease the expression of genes and are also effective in silencing the genes. DNA methylation, histone modifications, and non-coding RNAs are basic epigenetic mechanisms. Epigenetic modifications are also important for early embryonic development. Recent studies have reported that nutrient components are effective on epigenetic mechanisms. Bioactive components in foods have been of interest for epigenetic research. In this review, chromatin structure, basic epigenetic mechanisms have been explained and studies on nutrient components affecting epigenetic modifications have been given.
\end{abstract}

Keywords: Epigenetic, Nutrition, DNA methylation, histone modification

1. İletişim/Correspondence: SANKO Üniversitesi Sağlık Bilimleri Fakültesi, Beslenme ve Diyetetik Bölümü, Gaziantep, Türkiye E-posta: dmihcioglu@sanko.edu.tr • • https://orcid.org/0000-0003-2355-8026 


\section{GíRiş}

Genetik bilimi için bir dönüm noktası olan, deoksiribonükleik asitin (DNA) çift sarmal yapısı 1953 yılında James Dewey Watson ve Francis Crick adlı araştırmacıların yaptığı çalışmalar sonucunda bulunmuştur. Bu keşif genetik bilimi için bir dönüm noktası olmuştur. DNA' nin 3 boyutlu yapısının keşfinden 50 yll sonra ise 2003 yllında "İnsan Genom Projesi” ile genomu oluşturan yaklaşık üç milyar baz dizilenmiş ve kodlanan ve kodlanmayan bölgeler belirlenmiştir. Projenin bir diğer önemli sonucu ise; insan genomunun tüm insanlarda hemen hemen aynı olmasıdır (\%99.9). Genetik alanındaki bu gelişmelerden sonra terminolojiye yeni kelimeler eklenmiştir. Bunlardan bir tanesi de son ylllarda önemi her geçen gün artan "epigenetik" terimidir. "Epi” Yunanca “üzerinde” anlamına gelir. Epigenetik, DNA baz diziliminde herhangi bir değişiklik olmadan, gen ifade profilinin farklılaşarak sonraki kuşaklara aktarılmasıdır. Temel epigenetik mekanizmalar; DNA metilasyonu, histon modifikasyonları ve kodlanmayan RNA'lardır (1-4). Epigenetik faktörlerin önemli bir özelliği geri dönüşebilir olmasına ek olarak yaşam şekli ve beslenmeden (besin öğeleri ve biyoaktif bileşenlerden) etkilenebilmesidir (5)

Epigenetik mekanizmalar; yaşlanma, çevresel faktörler, diyetle alınan enerji ve besin ögeleri ile besin ögesi olmayan bileşikler (enerjinin fazla alınması /az alınması, metiyonin; $\mathrm{B}_{12}$, $\mathrm{D}$ ve $\mathrm{B}_{6}$ vitamini, biotin, kolin, selenyum, çinko, folik asit, resveratrol, kuersetin vb), sigara, alkol gibi etkenler ile etkileşim halindedir. Genom projesi sonrasinda her bireyin genotipinin farklı olduğu ortaya konmuştur. Genomda binlerce gen ve genlerin üzerinde dizilmiş 100.000 den fazla protein bulunmaktadır ve henüz tüm besin öğelerinin ve besin ögesi olmayan bileşiklerin gen ifadesinin düzenlenmesindeki rolü tam olarak açıklığa kavuşamamıştır.

$\mathrm{Bu}$ derlemenin amacl, epigenetik mekanizmalarda etkisi olduğu düşünülen biyoaktif besin bileşenleri ile yapılmış in vitro ve in vivo araştırma sonuçlarını sunmaktır.

\section{DNA ve Kromatin Yapı}

DNA kendini eşleyebilen, genetik bilgiyi hem saklayabilen hem de nesilden nesile aktarımını sağlayabilen bir moleküldür. DNA'nın yapıtaşları nükleotidlerdir. Nükleotidler, deoksiriboz, fosfat ve azotlu organik bazlardan oluşur (6). DNA'nın azotlu organik bazları Adenin (A), Timin (T), Guanin (G) ve Sitozin (S) olmak üzere dört tanedir. DNA çekirdek içerisinde katlanmış durumdadır.DNA'nın katlanmasına histon ve histon olmayan proteinler katılırlar. Histon proteinleri; H1, H2A, H2B, H3 ve H4'tür. DNA "nükleozom" adı verilen yapıların etrafına sarılmış şekilde bulunmaktadır. Nükleozom, 8 tane histon proteinin (her birinden ikişer tane bulunan; H2A, H2B, H3 ve H4) bir araya gelerek oluşturdukları oktamer yapıdır. Nükleozom yapısı histon proteinlerinin bir araya gelmesi ile oluşur. Nükleozomlar, kromatin yapının en temel birimidir (7).H1 histon proteini ise nükleozomları birbirine bağlar. Histon proteinlerinin kararlılığı, çok sayıda protein-protein etkileşimine, hidrojen bağlarına ve elektrostatik kuvvetlere bağlıdır (8).

Her nükleozom, 10-11 nanometre çapındadır. Her bir nükleozomun etrafina yaklaşık olarak 146 veya 147 baz çifti içeren DNA sarılmış şekildedir. Gen ekspresyonunun kontrolü ve genlerin düzenlenmesi histon proteinlerinin nükleozomun dışına doğru uzanan N-terminal kuyruklar ile gerçekleştirilir (9). Histon proteinlerinin kuyruklarl; asetilasyon, metilasyon, fosforilasyon vb. gibi modifikasyonlarla gen ifadesini etkiler. Nükleozom yapı, kendi üzerine dairesel şekilde katlanarak "selenoid" yapıyı oluşturur, selenoid yapının çapı 30 nanometredir. Selenoid yapı tekrar yoğunlaşarak loop adı verilen yapıyı oluşturur, looplu yapının çapı 300 nanometredir. Bu yapı da tekrar yoğunlaşarak kromozom yapısını oluşturur (10). Kromozomların üzerinde "heterokromatin” ve “ökromatin” adı verilen bölgeler bulunur. Heterokromatin bölgeler, proteinlerle sıkıca katlanmış durumdadırlar ve koyu renkli görünürler. Ökromatin bölgeler ise daha açlk 
renkte görülürler ve transkripsiyon açısından aktif bölgelerdir (11). Kromatin yapının, gen ekspresyonu sırasında katlanmış yapının açılıp, gen ekspresyonu olmadığında tekrar eski haline gelmesine kromatinin yeniden şekillenmesi adı verilir. Kromatinin yeniden şekillenmesinde epigenetik mekanizmalar etkilidir. Epigenetik mekanizmalar, temel olarak DNA metilasyonu, histon modifikasyonları ve kodlanmayan RNA'lar şeklinde sıralanır (12).

\section{DNA Metilasyonu}

DNA metilasyonu Sitozin bazının 5. C atomuna metil $\left(\mathrm{CH}_{3}\right)$ grubunun eklenmesi ile oluşur. Metillenmiş sitozinler çoğunlukla sitozin-guanin dinükleotitleri (CpG) adacıklarında bulunurlar (13). CpG adacıkları; 5'3'yönünde sitozin nükleotidini guanin nükleotidinin izlediği bölgelerdir. CpG adacıklarındaki "hipermetilasyon" transkripsiyonun baskılanmasına, "hipometilasyon" ise transkripsiyonun aktivasyonuna sebep olur (14). DNA metilasyonu transkripsiyon faktörlerinin DNA'ya bağlanmasını engelleyerek transkripsiyonun sessiz kalmasını indükler (15).

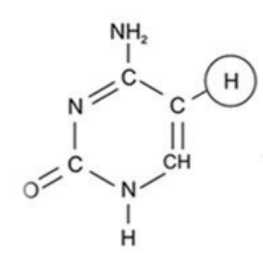

Sitozin

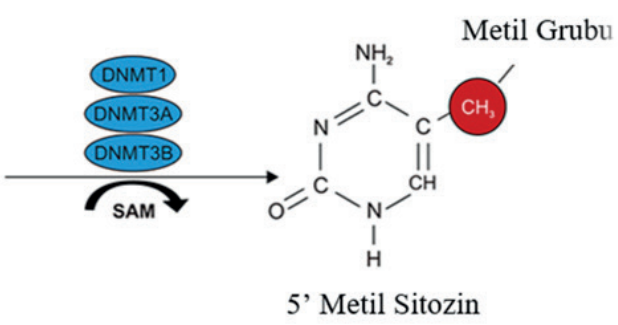

Şekil 1. DNA metilasyonu (16)

DNA metilasyonu; diyetten, birçok çevresel faktörden ve yaşam tarzından etkilenmektedir. Beslenme ile ilgili faktörler DNA metilasyonunda yer alan DNA metiltransferaz (DNMT) gibi enzimlerin aktivitelerini modifiye edebildiği gibi, S-adenozil metiyonin (SAM) sentezi için metil kaynaklarının kullanılabilirliğini değiştirebilir (17). DNA metilasyonu, DNMT enzimleri ve metil bağlama proteinleri aracılığıyla gerçekleşir. DNA metiltransferaz enzimlerinden DNMT1 enzimi yarı metillenmiş CpG bölgelerini metiller. DNMT3a ve DNMT3b enzimleri memelilerde gelişimin erken dönemlerinde ve germ hücrelerinde DNA metilasyonunun oluşumundan sorumlu olan metiltransferaz enzimlerindendir (18).

DNA metilasyonu sırasında eklenen metil gruplarının, metil kaynağı SAM’ dır. SAM metiyonin döngüsünden sentezlenir. Diyette bulunan metiyonin, folat, kolin, betain, çinko, selenyum ile $B_{2}, B_{6}$ ve $B_{12}$ vitaminleri döngünün farklı bölgelerinden katılarak SAM sentezine katkıda bulunur (19). SAM'daki metil grubu aktarıldıktan sonra SAM, S-adenozil homosisteine (SAH) dönüşür. SAM/SAH oranı DNA'nin hipermetilasyonu veya hipometilasyonu için metilasyon indeksidir (20). Yeşil çayda bulunan polifenoller, epigallokateşin-3 gallat (EGCG), soyada bulunan bir izoflavon olan genistein gibi biyoaktif bileşenlerin DNMT aktivitesini doğrudan ya da dolaylı olarak baskılama etkisinin olduğu belirtilmiştir (21).

EGCG, yeşil çayda bulunan bir polifenoldür. Meme kanseri hücre hattında yapılan çalışmada, EGCG’nin bir tümör baskllayıcı gen olan ve tümörlü meme dokularında hipermetile olan sinyal peptit, CUB ve EGF-benzeri domain-içeren protein 2 (SCUBE2) metilasyonunu tersine çevirerek, meme kanseri hücrelerinin büyümesini inhibe ettiği gösterilmiştir (22). Özafagus kanser hücre hattında 5-50 $\mu \mathrm{M}, 12-144$ saat EGCG ile muamele sonucunda DNMT aktivitesinin baskılandığı görülmüştür (23).

Kuersetin birçok sebze, meyve, çay ve propolis gibi farklı besin kaynaklarında bulunan bir flavonoiddir. Lösemi hücre kültüründe pro-apoptoz genleri ile yapılan bir çalışmada, 50 $\mu \mathrm{M}$ kuersetin uygulamasının genlerin promotor bölgelerindeki yüksek oranda metillenmiş bölgelerinde demetilasyona sebep olduğu rapor edilmiştir (24). Kuersetin ile bir başka çalışmada insan serviks kanseri hücre hattında yapılmıştır. İki farklı dozda ( $25 \mu \mathrm{M}$ ve $50 \mu \mathrm{M}$ ) kuersetin muamelesinin DNMT enzim aktivitesini düşürdüğü gözlenmiştir (25).

Resveratrolün kanser türlerinde DNMT enzimini inhibe edici etkisi olduğu bildirilmektedir. Meme kanseri olma riski yüksek olan 39 kadının dâhil 
edildiği bir çalışmada, grup kendi içinde üç alt gruba ayrılmış ve 12 hafta boyunca günde iki kez olmak üzere, birinci gruptaki kadınlara plasebo, ikinci gruptakilere $5 \mathrm{mg}$ resveratrol, üçüncü gruba ise $50 \mathrm{mg}$ resveratrol verilmiştir (26). Kanser ile ilişki olduğu bilinen 4 farklı gende serumda resveratrol seviyesi ile Ras ilişkili domain-1 (RASSF-1) genindeki metilasyon arasında negatif bir ilişki olduğu rapor edilmiştir. Buna göre resveratrol seviyesi arttıkça bir tümör baskılayıcı gen olan RASSF-1 geninin metilasyonunda azalma gözlemlenmiştir (26).

Meme kanseri hücre hattında farklı dozlarda ( $0,1,3$, 5, 10, 20, 30, 50 ve $100 \mu \mathrm{M}$ ) kurkumin muamelesinin tümör baskılayıcı gen olan Glutatyon S-transferaz P (GSTP1) geninin metilasyonuna etkisi incelenmiştir (27). Çalışmanın sonucunda, $10 \mu \mathrm{M}$ kurkumin muamelesinin GSTP1 geninin demetilasyonuna etkisi olduğunu ve bu genin reaktivasyonunu sağladığı gösterilmiştir. Ancak $3 \mu \mathrm{M}$ kurkumin ile muamele edilen hücrelerde promotor metilasyonunda herhangi bir değişiklik gözlenmemiştir. 20 ve $30 \mu \mathrm{M}$ kurkumin uygulandığında GSTP1 protein ekspresyonunda bir azalma olduğu belirtilmiştir (27).

\section{Histon Modifikasyonları}

Histon modifikasyonları post-translasyonel modifikasyonlar gibi oluşurlar. Bu modifikasyonlar, histon kuyruklarının $\mathrm{N}$ terminus kısımlarında gerçekleşen asetilasyon, metilasyon, fosforilasyon, biyotinasyon, sumozilasyon ve ubikitinasyondur. Histon modifikasyonları histon metiltransferazlar (HMT), histon demetilazlar (HDM), histon asetiltransferazlar (HAT) ve histon deasetilazlar (HDAC) tarafindan katalizlenir. HMT enzimleri histonların lizin veya arjinin rezidularına metil grubu eklerler. HDM enzimleri ise metil gruplarını çıkarırlar. Histon asetiltransferazlar histonların lizin rezidularına asetil grubu eklenmesini katalizlerken, histon deasetilazlar bu grupların çıkarılmasından sorumludur. Histonlarin hiperasetilasyonu baskılanmış genlerin aktivasyonu, hipoasetilasyonu ise genlerin sessizleşmesi ile sonuçlanır (28). Lizinin metillenmesi, transkripsiyonu aktive eder ya da baskllarken, arjinin metillenmesi ise transkripsiyonu aktive eder. Örneğin, H3K4me3 metilasyonu genin aktivasyonunu sağlarken, H3Kme9 ve/veya H3K4me27 ise geni inaktive eder (29).

İnsan serviks kanseri hücre hattında yapllan bir çalışmada; $50 \mu \mathrm{M}$ genistein ile muamele edilen kanserli hücrelerde, HDAC enzim aktivitesinin ve HMT enzim aktivitesinin inhibe olduğu gösterilmiştir (30). İnsan prostat kanseri hücre hattında 5- $20 \mu \mathrm{M}$ EGCG ile muamele edilen hücrelerde HDAC enziminin aktivitesinin inhibe olduğu ve tümör protein p53 (p53) geninin asetile olduğu gösterilmiştir (31). İnsan kolon kanseri hücre hattına hem genistein hem de EGCG muamelesi sonucunda HDAC1 protein seviyesinde anlamlı bir azalma ve HDAC enzim aktivitesinde inhibisyon olduğu belirtilmiştir (31).

Meme kanserli hücrelerde resveratrol ile yapılan bir çalışmada, hücrelere 48 saat uygulanan $20 \mu \mathrm{M}$ resveratrol sonrasinda HDAC enzim aktivitesinde azalma olduğu belirtilmiştir (32). Bir başka çalışmada, brokoli ve lahanada bulunan sülforafanın HDAC enzimini inhibe ettiği belirtilmiştir (33).

\section{Kodlanmayan RNA'lar (ncRNA)}

Temel epigenetik mekanizmalardan bir diğeri de kodlanmayan RNA'lardır. DNA'nın dizilenmesinden sonra, genomun büyük bir kısmının kodlanmayan RNA'lardan oluştuğu görülmüştür. ncRNA'lar translasyona uğramayan ve gen ifadesinin düzenlenmesinde rol alan önemli bir bileşendir. Aynı zamanda transkripsiyon sonrasinda gen ekspresyonunun regülasyonunda yer alırlar. Kodlanmayan RNA'lardan önde gelenler küçük interferans RNA (siRNA) ve mikroRNA (miRNA)'lardır. Kodlanmayan RNA' lar mRNA degredasyonu ya da translasyonun oluşumunu engelleyerek genlerin sessizleştirilmesinde etkili olmaktadırlar (33). Epigenetik mekanizmalar, transkripsiyonel düzensizliklere sebep olarak onkogenlerin ve/ veya tümör baskılayıcı genlerin uygun olmayan ekspresyonuna ya da inaktivasyonlarına sebep olabilirler (34). 
Serviks kanseri hücre hatlarında, EGCG biyoaktif bileşeninin çeşitli yolaklarda etkin olan farklı miRNA'lara etkisini belirlemek için çalışma yapılmıştır. Çalışmada hücre hatlarına, farklı konsantrasyonlarda $(100,80,60,40,20,10$ ve $0 \mu \mathrm{g} / \mathrm{mL})$ EGCG uygulanmıştır. Çalışmanın sonucunda, EGCG biyoaktif bileşeninin serviks kanseri hücre hatlarında, miRNA'ların ekspresyon seviyelerini değiştirerek hücre proliferasyonunu baskıladığı belirtilmiştir (35).

İnsan pankreas hücre hatlarında, 72 saat süre ile kurkumin ile muamele edilen hücrelerde miRNA ekspresyon seviyelerinde değişiklik olduğu gözlenmiştir. Özellikle miRNA-22 ekspresyonu anlamlı derecede artarken, miRNA-199a ekspresyonunun ise anlamlı derecede azaldığı gösterilmiştir (36). İnsanlarda yapılan bir çalışmada; yaş ortalaması 39 olan obez 54 yetişkin kadın bireyler iki gruba ayrılmış, gruplardan birine 60 gün boyunca günde bir tane ortalama ağırlığı 5 g olan selenyum içeriği zengin olan brezilya cevizi verilmiştir. Çalışmanın sonucunda, miR-454-3p ve miR-584-5p seviyelerinde artış olduğu rapor edilmiştir (37).

Biyoaktif bileşenlerin epigenetik mekanizmaları etkileyerek, tümör baskllayıcı genlerin ifadesini değiştirmelerinin yanı sıra nörodejeneratif ve kardiyovasküler hastalıkların ilerlemesinde etkili olabilmektedir (38-40). Yaşlı Alzheimer hastalarında yüksek oranda tüketilen A, E, C vitaminlerinin ve karotenin hastalığın ilerlemesini yavaşlattığını bildirmişlerdir (38). Kurkuminin de Alzheimer hastalığının seyrini yavaşlattığı bildirilmiştir $(39,40)$. Farelerde yapılan bir araştırmada, kurkuminin HAT, HDAC enzimlerini inhibe ederek, kalp yetmezliğini önlediği rapor edilmiştir (39). Yine farelerde yapılan bir çalışmada ise, genisteinin humoral ve hücresel bağışıklığı modüle ettiği gösterilmiştir (40) .

\section{SONUÇ VE ÖNERİLER}

Epigenetiği oluşturan mekanizmalar; DNA metilasyonu, histon modifikasyonları ve kodlanmayan RNA'lar olarak tanımlanmaktadır. Epigenetik mekanizmaların, biyoaktif besin bileşenlerinden etkilendiği son yıllarda yapılan çalışmalar ile ortaya konmuştur. Doğada binlerce sayıda bulunan polifenollerden literatürde en çok çalışılan genistein, kurkumin, resveratrol, sulforofan, epigallokateşin-3 gallat gibi biyoaktif bileşenlerin epigenetik mekanizmaları modüle edebildiği ve çeşitli genlerin özellikle de tümör baskılayıcı genlerin ifadesini değiştirdiği, ayrıca bazı hastalıkların oluşma ve ilerleme evresinde etkili olabileceği gösterilmektedir. Aynı zamanda son yıllarda ki çalışmalar epigenetik mekanizmalar ile kalori kısitlaması arasında bir ilişki olabileceğini ve kronik hastalıkların azaltılması ile organizmanın uzun bir yaşam süresinin olabileceğini öne sürmektedir. Nutriepigenomik alanındaki çalışmalar hızla devam etmekte olup diyet bileşenlerinin optimum dozunun ve olası risklerinin belirlenmesi için daha fazla klinik çalışmaya ihtiyaç duyulmaktadir.

Çıkar çatışması - Conflict of interest: Yazarlar çıkar çatışması olmadığını beyan ederler. - The authors declare that they have no conflict of interest.

\section{KAYNAKLAR}

1. Kennedy BK, Berger SL, Brunet A, Campisi J, Cuervo AM, Epel ES, et al. Geroscience: linking aging to chronic disease. Cell. 2014;159(4):709-13.

2. López-Otín C, Blasco MA, Partridge L, Serrano M, Kroemer G. The hallmarks of aging. Cell. 2013;153(6):1194-217.

3. Pal S, Tyler J. Epigenetics and aging. Sci Adv. 2016;2(7):e1600584.

4. Sen P, Shah PP, Nativio R, Berger SL. Epigenetic mechanisms oflongevity and aging. Cell. 2016;166(4):82239.

5. Bacalini MG, Friso S, Olivieri F, Pirazzini C, Giuliani C, Capri M, et al. Present and future of anti-ageing epigenetic diets. Mech Ageing Dev. 2014;136:101-15.

6. Travers A, Muskhelishvili G. DNA structure and function. The FEBS journal. 2015;282(12):2279-95.

7. Tessarz P, Kouzarides T. Histone core modifications regulating nucleosome structure and dynamics. Nat Rev Mol Cell Biol. 2014;15(11):703-8.

8. Davey CA, Sargent DF, Luger K, Maeder AW, Richmond TJ. Solvent mediated interactions in the structure of the nucleosome core particle at $1.9 \AA$ resolution. J Mol Biol. 2002;319(5):1097-113.

9. Luger $\mathrm{K}$, Richmond TJ. The histone tails of the 
nucleosome. Curr Opin Genet Dev. 1998;8(2):140-6.

10. Luger K, Dechassa ML, Tremethick DJ. New insights into nucleosome and chromatin structure: an ordered state or a disordered affair? Nat Rev Mol Cell Biol. 2012;13(7):436.

11. Riaz S, Sui Z. Molecular cloning, transcriptome profiling, and characterization of histone genes in the dinoflagellate Alexandrium pacificum. J Microbiol Biotechnol. 2018;7:1185-98.

12. Kobayashi W, Kurumizaka H. Structural transition of the nucleosome during chromatin remodeling and transcription. Curr Opin Struct Biol. 2019;59:107-14.

13. Bird A. DNA methylation patterns and epigenetic memory. Genes Dev. 2002;16(1):6-21.

14. Bird A. The essentials of DNA methylation. Cell. 1992;70(1):5-8.

15. Bird A. Methylation talk between histones and DNA. Science. 2001;294(5549):2113-5.

16. Bae D-J, Jun J, Chang HS, Park JS, Park C-S. Epigenetic Changes in Asthma: Role of DNA CpG Methylation. Tuberc Respir Dis.2019;82.

17. El Gendy K, Malcomson FC, Lara JG, Bradburn DM, Mathers JC. Effects of dietary interventions on DNA methylation in adult humans: systematic review and meta-analysis. Br J Nutr. 2018;120(9):961-76.

18. Jurkowska RZ, Jurkowski TP, Jeltsch A. Structure and function of mammalian DNA methyltransferases. Chembiochem. 2011;12(2):206-22.

19. Parrillo L, Spinelli R, Nicolò A, Longo M, Mirra P, Raciti GA, et al. Nutritional Factors, DNA Methylation, and Risk of Type 2 Diabetes and Obesity: Perspectives and Challenges. Int J Mol Sci. 2019;20(12):2983.

20. Kadayifci FZ, Zheng S, Pan Y-X. Molecular mechanisms underlying the link between diet and DNA methylation. Int J Mol Sci. 2018;19(12):4055.

21. Mahmoud AM, Ali MM. Methyl Donor Micronutrients that Modify DNA Methylation and Cancer Outcome. Nutrients. 2019;11(3):608.

22. Sheng J, Shi W, Guo H, Long W, Wang Y, Qi J, et al. The Inhibitory Effect of (-)-Epigallocatechin-3Gallate on Breast Cancer Progression via Reducing SCUBE2 Methylation and DNMT Activity. Molecules. 2019;24(16):2899.

23. Wang L-X, Shi Y-L, Zhang L-J, Wang K-R, Xiang L-P, Cai Z-Y, et al. Inhibitory Effects of (-)-Epigallocatechin-3gallate on Esophageal Cancer. Molecules. 2019;24(5):954.

24. Alvarez MC, Maso V, Torello CO, Ferro KP, Saad STO. The polyphenol quercetin induces cell death in leukemia by targeting epigenetic regulators of pro-apoptotic genes. Clin Epigenetics. 2018;10(1):139.

25. Kedhari Sundaram M, Hussain A, Haque S, Raina
R, Afroze N. Quercetin modifies 5' CpG promoter methylation and reactivates various tumor suppressor genes by modulating epigenetic marks in human cervical cancer cells. J Cell Biochem. 2019.

26. Farhan M, Ullah MF, Faisal M, Farooqi AA, Sabitaliyevich UY, Biersack B, et al. Differential methylation and acetylation as the epigenetic basis of resveratrol's anticancer activity. Medicines. 2019;6(1):24.

27. Hardy TM, Tollefsbol TO. Epigenetic diet: impact on the epigenome and cancer. Epigenomics. 2011;3(4):503-18.

28. Kumar U, Sharma U, Rathi G. Reversal of hypermethylation and reactivation of glutathione S-transferase pi 1 gene by curcumin in breast cancer cell line. Tumor Biol. 2017;39(2):1010428317692258.

29. Toraño EG, Fernandez AF, Urdinguio RG, Fraga MF. Role of epigenetics in neural differentiation: implications for health and disease. Molecular mechanisms and physiology of disease: Springer; 2014. p. 63-79.

30. Sundaram MK, Unni S, Somvanshi P, Bhardwaj T, Mandal RK, Hussain A, et al. Genistein Modulates Signaling Pathways and Targets Several Epigenetic Markers in HeLa Cells. Genes. 2019;10(12):955.

31. Gao Y, Tollefsbol TO. Cancer chemoprotection through nutrient-mediated histone modifications. Curr Med Chem. 2015;22(17):2051.

32. Chatterjee B, Ghosh K, Kanade SR. Resveratrol modulates epigenetic regulators of promoter histone methylation and acetylation that restores BRCA1, p53, p21CIP1 in human breast cancer cell lines. BioFactors. 2019.

33. Bishop KS, Ferguson LR. The interaction between epigenetics, nutrition and the development of cancer. Nutrients. 2015;7(2):922-47.

34. Krakowsky RH, Tollefsbol TO. Impact of nutrition on non-coding RNA epigenetics in breast and gynecological cancer. Front Nutr. 2015;2:16.

35. Zhu Y, Huang Y, Liu M, Yan Q, Zhao W, Yang P, et al. Epigallocatechingallateinhibits cellgrowthandregulates miRNA expression in cervical carcinoma cell lines infected with different high-risk human papillomavirus subtypes. Exp Ther Med. 2019;17(3):1742-8.

36. Reuter S, Gupta SC, Park B, Goel A, Aggarwal BB. Epigenetic changes induced by curcumin and other natural compounds. Genes Nutr. 2011;6(2):93-108.

37. Reis BZ, Duarte GBS, Vargas-Mendez E, Ferreira LRP, Barbosa Jr F, Cercato C, et al. Brazil nut intake increases circulating miR-454-3p and miR-584-5p in obese women. Nutr Res. 2019;67:40-52.

38. Wengreen H, Munger R, Corcoran C, Zandi P, Hayden $\mathrm{K}$, Fotuhi M, et al. Antioxidant intake and cognitive function of elderly men and women: the Cache County Study. J Nutr Health Aging. 2007;11(3):230. 
39. Morimoto T, Sunagawa Y, Kawamura T, Takaya T, Wada H, Nagasawa A, et al. The dietary compound curcumin inhibits p300 histone acetyltransferase activity and prevents heart failure in rats. J Clin Invest. 2008;118(3):868-78.
40. Yellayi S, Zakroczymski M, Selvaraj V, Valli V, Ghanta $\mathrm{V}$, Helferich WG, et al. The phytoestrogen genistein suppresses cell-mediated immunity in mice. J Endocrinol . 2003;176(2):267-74. 